\title{
Mutcah and Ciddah Maintenance: A Critical Analysis on the Implementation in the Context of the Family Law of Thailand and the Islamic Family Law of the Southern of Thailand
}

Rohanee Machae

Abdul Basir Mohamad

Mutsalim Khareng

\begin{abstract}
Correspondences: Rohanee Machae. Ph.D. Candidate Department of Syariah, Faculty of Islam Studies
\end{abstract} National University of Malaysia; Email: nee_2750@hotmail.com

Doi:10.5901/mjss.2015.v6n6s4p241

\section{Abstract}

The issue on Mutcah and clddah maintenance after divorce has been a continuous debate since decades ago among the Muslim scholars. The Muslim women in the Southern of Thailand are not exempted from this issue. This mini research is meant to identify the implementation of the right of Mutcah and clddah maintenance in the context of the Family Law of Thailand and the Islamic Family Law of The Southern of Thailand. As the approach to obtain the findings, this research used content analysis on the previous researches conducted by the local scholars. The findings show that the right of Mutcah and clddah maintenance is placed at the high level in Islam as it is compulsory for the husband who divorced the wife to give the right throughout the clddah period. Besides, the right of Mutcah and clddah maintenance is also found in both laws. Even though it is not clearly stated as Mutcah and c/ddah maintenance in the Family Law of Thailand, the protection and assurance given by the husband who divorced the wife are listed. Hence, it has been proven that the rights of women who have been divorced by the husbands are still protected as long as they do not break the conditions listed by both laws.

Keywords: Mutcah, cIddah Maintenance, The Islamic Family Law, The Islamic Family Law of Thailand.

\section{Statement of the Problem}

Islam, the comprehensive way of life has thoroughly listed all issues related to marriage, divorce and reconciliation as the law guidance that is compulsory to be followed by Muslims. By referring to the issue of divorce, there are few aspects to be highlighted such as maintenance for the wife, children custody, children maintenance and distribution of wealth. The issue on Mutcah and maintenance during the period of $c / d d a h$ to the divorced wife has also been the crucial debate among the Muslim scholars.

The study is focusing on the Mutcah and c/ddah maintenance that is compulsory to be provided by the husband after he divorced his wife. The obligation is established by Islam as to protect the welfare of a woman after being divorced by her husband. The existing facts suggest that the Muslim women who have been divorced by their husband will face many problems such as the difficulty of raising the children alone, experience financial problem that leads to poverty as they do not have any occupation as the source of income. In addition, living in the world of information and communication technology today is greatly affecting those weak women. Hence, it should be a concern to protect those women as they can easily be victimized and repressed as Islam is greatly protecting the women and placing them in the high status.

The issue of providing and receiving Mutcah and c/ddah maintenance occurs everywhere and always been argued by both parties involved in divorce. Thus, it is not an exemption for the Muslims in the Southern of Thailand to experience the same problem as the local scholars have been debating on the issue of Mutcah and clddah maintenance in the conferences and forums. Based on the Marriage and Divorce Statistics (2006-2012), the claim on Mutcah and c/ddah maintenance is increasing among the society of the Southern of Thailand.

In brief, as the divorce cases increased, the failure of providing Mutcah and c/ddah maintenance cases among the husband and the ex-wife will also increase. The failure will also lead to the claim of Mutcah and c/ddah maintenance by the ex-wife as they are facing poverty after being divorced and affecting the children education. In addition, the case will be coming worst if the divorce happened because of the great conflict as reported in the newspapers or other 
organizations (Lettanongsak, S. 2008). Therefore, this research aims to identify the level of protection of the right of Mutcah and c/ddah maintenance by the Family Law of Thailand and the Islamic Family Law of the Southern of Thailand.

\section{Research Methodology}

This research used qualitative approach that apply content analysis method. The data gathered was analyzes deductivel, inductively as well as comparative method. Furthermore, the research materials used are the primary and secondary books.

\section{The Status of Mutcah and clddah Maintenance in Islam}

\subsection{Mutcah}

The word Mutcah in the al-Munjid fi al-Lughah is mentioned as something that is taken from its benefit. It is a kind of payment or consolation gift which is given by the ex-husband to the ex-wife in the form of things or money (Louwis, M. 1986). Based on syarak, Mutcah is defined as a sum of property that is compulsory to be paid by the husband to the wife when they get divorce either by talaaq or any similar ways based on certain conditions (Ibn Qudamah, 1981). Al-Shafici defined Mutcah as the property that is compulsory for the husband to pay it to the ex-wife who has been divorced by talaaq when she is still alive or in any similar conditions based on certain conditions (al-Khatib, S. 1994). Apart from that, Al-Zahyli, W. gave the definition of Mutcah as a noble act done by the husband to the wife who has been divorced, according to the husband's financial standings (Zuhayli, W. 1985). In brief, there are two different definitions of Mutcah, that lead to different laws related to it, and it will be explained further in the laws explanation part.

The purpose of implementing the law of Mutcah is to ease the burden and sadness experienced by the women who have been divorced. It is also a form of gift that is determined by the Islamic law to the ex-wives in that condition. Other than that, it is meant to improve the relationship and lessen the suffering of the ex-wives. This in line with the words of Allah (S.W.T) in Surah Al-Baqarah 1:236.

In discussing the law of Mutcah, Islamic scholars have different opinions in determining the giving of Mutcah to the divorced wife. Based on the unanimous opinion of the Islamic scholars, Mutcah is compulsory to be given to the divorced wife who has not been in the sexual intercourse with the husband, and the mahr is not mentioned during akad. This is in line with the words of Allah (S.W.T) in Surah Al-Baqarah 2:4 (al-Shairazi, A. I.1967). Nevertheless, Abu Thur in Rawa'i alBayan Tafsir Ayat al-Ahkam Min al-Qur'an claimed that Mutcah should be given to the wives who have been divorced as the wives entitled to get half of the mahr after they were divorced, as well as Mutcah from their ex-husbands. Meanwhile, Al-Basri, H. Said that, it is compulsory to give Mutcah to all divorced wives, regardless their mahr was mentioned during the akad or not. On the other hand, according to the Maliki sect, giving Mutcah is sunnah, as it is not compulsory to give Mutcah to the divorced wife (al-Sabuni, M. A.1977).

In the opinion of Abu Qasim, Mutcah is the right of a wife that should be given to her and that could be something that can be listed as inheritance. That means, if the Mutcah is not given because of ignorance or the husband has missed few years before, the husband has to give it even though the ex-wife has been in a new marriage, or if the ex-wife is dead, the Mutcah should be given to the ex-wife's heir (al-Qurtubi, A. A. 1967). In this case, the sect of Al-Shafici, it is encouraged to give Mutcah as it will ease the burden of the ex-wives as well as opening the room for the relationship of the husband and wife to become closer if their case is not from talaaq ba'in.

In determining the rate of Mutcah, Islam did not set the fix rate for that as it depends on the ex-husband's financial ability, if he is a rich person, he should give the Mutcah based on his wealth. A poor and moderate living husband should give the Mutcah based on his financial standings, as Allah (S.W.T) said in Surah Al-Baqarah 2:236. Moreover, a hadith narrated by Ibn 'Abbas from 'Aeshah which is said that Mutcah is supposed to be the three pieces of clothes, as women use them for solah or any other outdoor activities (al-Sarkhasiyy, S. D. n.d.). In the sect of al-Shafici, it is encouraged (sunnah) to give Mutcah as scarf or money for 30 dirham as both of them possess different values. In order to determine whether the ex-wife is entitled to get the scarf or the 30 dirham, it is still based on the ex-husband's financial ability (alShairazi, A. I. 1967). In addition, Al-Khatib, S. also stated that if any misunderstanding occurs on the rate of Mutcah, they should take into consideration on the ex-husband's financial ability, as well as the status, bloodline and characteristics of the ex-wife (al-Khatib, S. 1994). Besides, in the sect of Hanafi, the rate of Mutcah should follow the three clothes which is first is for the woman to wear it at home, second is for the woman to cover their head and third is for the woman to cover her body from head to toe. On the other hand, the sects of Maliki and Hambali stated that the rate of Mutcah should be based on the husband's financial ability, which means if the husband is rich, the rate should be higher and if the husband 
is poor, the rate should be lower (Zuhayli, W. 1985).

Based on the unanimous opinions of the Islamic scholars, it can be concluded that Mutcah is given by the husband to the ex-wife as consolation gift to the ex-wife after the divorce. However, it is important to know that, the rate of Mutcah should be determined by the Judge's evaluation. This is because, the judge will analyze the financial standing and ability of a husband, before fixing the rate of Mutcah for his ex-wife. Nonetheless, it also depends on the agreement between the husband and wife regarding the rate, as the actual right still goes to the wife to determine it.

\section{2 c/ddah Maintenance}

Apart from Mutcah, c/ddah maintenance is one of the husband's obligations to be fulfilled to the divorced wife during the period of $/ d d a h$. The phrase c/ddah maintenance is not mentioned as a word, as it is a combination of two words which are 'maintenance' and 'clddah'. Maintenance in Arabic is derived from the word nafaqa; al-Nafaqah is the noun from the word al-infaq which means to spend something in a form of money. Hence, the phrase can be defined as providing the needs of a wife, for instance the food, cloth, shelter and other relevant necessities (Qalcah, M. R. 2006). Meanwhile, $c / d d a h$ is derived from the Arabic word al-c $A d d$ which means measurement or calculation. The meaning of the term c/ddah is a period which is determined by the Islamic law after the confirmation of divorce, where the ex-wife has to wait for that particular period to end without having a new marriage (Zuhayli, W. 1985). In the definition of al-Khasht, c/ddah is defined as the waiting period for a woman after she has been divorced by the husband. During the period of $c / d d a h$, the wife is not allowed to leave the husband's house and the husband is prohibited to chase the wife from his house. Therefore, it is compulsory for the husband to provide the maintenance until the period ends (al-Khasht, M. U. 1994).

There are three conditions of divorce which are talaaq rajci, talaaq ba'in and talaaq because of the death of the husband. If the divorce happened in the condition of talaaq raji, the figh scholars unanimously decided that the husband is obligated to provide the maintenance such as the food, cloth and shelter during the clddah period. During that period, the wife is not allowed to leave the shelter provided by the husband, as well as the husband is prohibited from chasing the wife from the house, except the wife is recognized as nusyuz (disloyal). This is meant to give the opportunity for them to fix the existed husband and wife relationship. That means, the husband and wife relationship is void as the c/ddah period ends, and they should leave the house that they used to stay before; as Allah (S.W.T) mentioned in Surah AlTalaaq, verse 6 (al-Ansari, A. M, 1949; al-Zahayli, W. 1994).

In the book Matan Abi Sujac, it is stated that "women who have been divorced by talaaq rajci have the right for the shelter and maintenance during the period of c/ddah" (Al-Ghayah wa Al-Taqrib). The next statement is taken from the book Kifayah Al-Akhyar, "providing expenses (maintenance) to a loyal wife (who completely obeys the husband) is compulsory, based on the husband's financial ability; if the husband is rich, the rate of maintenance for food should be a double of what they have used to eat, and clothes as what the middle status people use. If the husband is from the middle class people, the rate should be one and a half of food and clothes as what the middle status people use" (alDimashqi, T. $1428 \mathrm{H}$ ).

The following condition is for the wives who have been divorced by talaaq ba'in, they will receive the maintenance and shelter if they are pregnant, and if they are not pregnant, there are few opinions regarding it. According to Imam AlShafici, the wives are entitled for the shelter, but not the maintenance as their relationship is void (al-Khatib, M. 1958). In brief, the Islamic scholars have unanimously agreed that the pregnant wives who have been divorced by talaaq ba'in are entitled to receive the maintenance and shelter as mentioned by Allah (S.W.T) in Surah Al-Talaaq verse 6.

As a result, the husband is compulsory to provide shelter in all conditions of divorce; talaaq rajci, talaaq ba'in and talaaq because of the death of the husband. However, for the wives either they are pregnant or not, who are in the period of c/ddah because of the death of their husbands, they are not entitled to any maintenance as the dead does not have the responsibility towards the living people. By referring to the hadith narrated by Furayah binti Malik, Rasullullah (P.B.U.H) ordered her to live in the house for four months and ten days as the period of c/ddah.

Following that, Imam al-Shafici stated that the wives are entitled to get the shelter for four months and ten days as the clddah period (al-Maumani, I. 2010).

Thus, the property of the death should not be sold as to pay off the debt, until the wife has finished the c/ddah period. However, if the heir of the dead fails to provide the shelter, the judge can order the heirs to provide it as it is the right of Allah that should be obeyed. The statement is supported by Imam Al-Syafi'l and Imam Malik who agreed that the divorced wives either by talaaq rajci, or talaaq because of the death of the husband who are in the period of c/ddah are entitled to get the shelter. Nonetheless, for the separation that happened in the condition of li'an, there is no maintenance entitled for the wife as this condition is not in the category either the divorced wife or the death of the husband (Farj, A. 1990). 
Next, the wife maintenance in the case of her husband is lost. If the husband is certified as lost without any news, and it will take a long time to find him, the wife can take his property as the maintenance. However, if the lost husband does not have any property, the court or judge can proclaim the divorce as during the time of Umar (R.A.); he ordered the husbands who left their wives to give maintenance or divorce them (al-Yamani, S. n.d.).

Conversely, if the husband is reluctant to provide the maintenance, the judge can order the wife to take the husband's property as the maintenance for her. This is because; the wife could be victimized if the right is not fulfilled. Hence, the cruelty should be overcome by all means including using the court order in order to use the husband's property. Nevertheless, if it is too difficult for the wife to get the husband's property, she is allowed to take debt. Besides, the welfare institution as baitulmal can help the poor wife to get the maintenance. However, if all the efforts taken are not working, the separation could be the last resort for them.

\section{Critical Analysis on Mutcah and c/ddah Maintenance in the Family Law of Thailand and the Islamic Family Law of the Southern of Thailand}

Thailand is a multi-religious country that implements the law which can balance the various aspects including the family aspect. There are two laws implemented in Thailand which are the Civil and Commercial Code Chapter 5 and Chapter 6 and the Islamic Family Law of the Southern of Thailand (Bundet. P. 1998). The Islamic Law is only relevant to the Muslims who are living in the four districts of Thailand which are Pattani, Narathiwat, Yala and Satul, but the civil law is enforce to all Thailand citizens except for the four mentioned districts. However, the civil law can be implemented on the Muslims if the plaintiff or defendant are not living in the four districts of the Southern of Thailand (Muhammad K. Z. 1996). For that reason, the discussion will be divided into two sections which are Mutcah and c/ddah maintenance as written in the Islamic Family Law of the Southern of Thailand or named as "Lak Kodmai Islam Waduaiu Krobkrua Law Morodok" (Kaedah Undang-Undang Islam: Keluarga dan Pusaka). The definition of Mutcah written in the Civil and Commercial Code Chapter 5 and Chapter 6 is compensation, even though the actual meaning of maintenance is the living expenses of the wife after the divorce. Even though both words are interpreted differently in both laws, but in practice they are gift provided by law to protect a wife after the divorce

\subsection{Mutcah}

The right of Mutcah is the obligated right of a husband to a wife after she has beendivorced because of invalid reason. Even though the Islamic scholars have different opinions on the right of Mutcah for the divorce which is caused by the wife, the judge claimed that it is not a big issue in most of the cases at the court or the Islamic council. The benefit of giving Mutcah to the wife is to ease their burden after being divorced by the husband. Besides, she can start a new life alone, or before she get into the new marriage or before she reconciles with the former husband.

Provision of the Islamic Family Law of the Southern of Thailand item 295-297 is related to Mutcah or the consolation gift for the divorced women without any valid reason. The provision stated that a wife is entitled for the Mutcah or the consolation gift from the husband after the divorce. Even though the rate of Mutcah or the amount to be paid is not specifically stated in the item, it mentioned that the money should be given in a relevant amount based on the Islamic law. The provision item 295 defined Mutcah as follows:

The property given by the husband to the wife after the divorce because the wife is divorced by the husband or in other condition, should follow the first sentence which is relevant to the giving of mahr in this law (Islamic Family Law of the Southern of Thailand item 295).

The above item can be explained as the giving of Mutcah should be done by the husband to the wife after their divorce based on his financial standing, either in the form of money or things, as long as the divorce is not caused by the wife's action. Mutcah cannot be accepted if the divorce is caused by the wife such as the wife commited apostasy, or the wife claimed for fasakh because of her shame (weakness) or the husband's shame. This is the same in the case of the death of the husband or wife, where the wife is not entitled to get the Mutcah. The giving of Mutcah is not only for the divorced wife, but it is also for the divorced wife who has been in the sexual intercourse with the husband. Similarly, the wife who has been divorced before having sexual intercourse with the husband and did not receive any mahr from the husband till they get divorced. This case can be referred to the provision of law item 296 :

A husband should give Mutcah to the wife after the divorce which is not caused by the wife, except the separation is caused by the death of the husband or wife, if the marriage

a) The divorced wife has been in the sexual intercourse with the husband

b) The divorced wife has not been in the sexual intercourse with the husband and has never received any mahr 
from the husband till the time of the divorce and after the divorce happened.

The rate of Mutcah has always been a debate between the plaintiff and the defendant. Some laws stated that the rate of Mut ah should follow the financial standing of the husband, but Islamic Family Law of the Southern of Thailand has stated that the rate of Mutcah in the provision item 297 as follow:

The rate of Mutcah should be determined by the agreement between the husband and the wife, but if they did not have an agreement on that, the judge should make the decision based on the financial standing of the husband and wife during the divorce. However, the rate of mahr should be started from 30 dirham and above, and it should not exceed half of the wife's mahr. (Islamic Family Law of the Southern of Thailand item 297).

By referring to the statements above, it can be summarized that the husband and wife should have an agreement on the rate of Mutcah. Nevertheless, if the husband and wife did not have any agreement on that, the judge should determine the rate based on the financial ability of the husband and wife. In addition, the rate should start from 30 dirham or more as long as it does not exceed half of the mahr given by the husband during their marriage. This is supported by Imam al-Shafici with the statement that rate should not be lesser than 30 dirham or based on the ability of someone (alAnsari. 1968).

In the case of Che Hajar Bunga vs. Ahmad Soh, Datuk Yutitam (the judge) of Pattani has stated that the rate of Mutcah as listed by Islamic law is by looking at the situation of the husband and the wife's characteristics. Characteristic is the attitude while situation is the family status in the society. Rich and poor is the current value of owning and posesssing. As far as the rate of Mutcah is concerned, there is no specific formula or method to determine it. Hence, the decision based on the rate should not be lesser than 30 dirham based on the law is used. Briefly, there are various methods and formulas that are used by the plaintives in justifying their amount of claim for Mutcah at the court of the Islamic Council (An interview : Datuk Yutitam (Judge);Pattani 5/5/2015)

There are also cases where the plaintiff use the Bath calculation formula per day or per month and it is multiplied with the term of marriage. This has also been a common practice in evaluating the amount of claim that is meant to be filed at the court or the Islamic Council for the Mutcah from the husband. Nonetheless, Mutcah is about the agreement of both parties, but if they do not have the agreement, the judge will determine the rate of it. There is also no hadith or evidence determining the exact rate of Mutcah. Thus, the judge should discuss and determine the rate (An interview : Hj.Solahuddin Hj.Abdullatif (Committee of the Islamic Council of the Southern of Thailand);Pattani 5/5/2015).

In the provision of the Family Law of Thailand, the protection of a wife after a divorce and the receiving of Mutcah are not mentioned as it is a different matter in the creation of law. This is also because the Islamic law is created by Allah (S.W.T) based on the Quran and Sunnah. Meanwhile, the Civil law is created by the government of human being based on the mind and desire and the form is determined by the wish, need and ambition. However, Mutcah is mentioned in the Family Law of Thailand as compensation after divorce, in order to protect the woman or wife.

Mutcah or consolation gift in the Family Law of Thailand is a compensation which is not similar to the law, but it is a protection for the wife after a divorce. The compensation is valid if the husband or wife is being unfaithful or keeping a mistress or committing adultery, and the other party can file for fasakh. Based on the law provision item 1523, the compensation can be defined as:

If a divorce happened by the Court order because of the explanation in item 1516(1), a husband or wife is entitled to get the compensation from the husband or wife or any party that caused the divorce. A husband can claim for the compensation from the lover of his wife and the wife can claim for compensation from the lover of her husband. If the husband or wife admitted their guilt, they do not have any right for the compensation as mentioned in the provision item 1516(1) (Civil and Trade Code Chapter 5 and Chapter 6 item 1523).

The item 1523 above stated that if the divorce happened by the Court order as the husband or the wife is unfaithful or having an affair with someone else and committing adultery. This will cause one party to live in shame and sorrow, so the husband or the wife can claim for the compensation from one party. The claim can also be made for the third party who caused the divorce, for instance the husband or the wife who has an affair with the third party. The compensation can be claimed if they did not register the divorce and declared as ex-husband and ex-wife. If the divorce is registered, the right for compensation is absence as both parties agreed to get divorce and the divorce is considered as the final decision.

This issue can be seen in the court decision mail no. 3120/2530 which stated if the husband and wife get divorce, the wife is not allowed to claim the compensation from the husband or the woman of her husband's affair. Nevertheless, if they have not registered their divorce, or the fasakh application is in progress at the court, they are still considered as husband and wife, and the wife can claim for the compensation from the involved party (The judgment of the Supreme Court No. 3120/2530). However, if the divorce happens with the agreement of each other's affair, both parties cannot claim for the compensation as mentioned in item 1516(1). 
Generally, the claim for compensation can be made in two conditions which is firstly, claiming the compensation from the husband or the wife who is having an affair based on item 1523(First Paragraph). Secondly, the husband or the wife can claim for compensation from the lover of the husband or the wife based on item 1523(Second Paragraph). However, if both the husband and wife agreed to the love affair of each other, both of them cannot claim for the compensation from each other, as well as from the third party. The clarification of this provision can be seen in the court decision mail no 320/2530 where the sexual affair under the provision item 1523(Second Paragraph) which explains on the unfaithful act of the husband or wife. The decision on the payment of compensation is not necessarily accompanied by the fasakh application from the husband or wife, as the provision gives the right to the husband or wife to directly claim for the compensation. Since having an unfaithful affair is illegal, the court can ask for compensation from them. In the above case, the plaintiff claimed for compensation from the defendant for being unfaithful with $\mathrm{N}$. On the other hand, the defendant claimed that the plaintiff has agreed to the love affair of the defendant with $\mathrm{N}$, as $\mathrm{N}$ is the wife of the plaintiff . Therefore, the court decided that the plaintiff is not entitled to claim for the compensation from the defendant based on provision item 1523(Third Paragraph). (The judgement of the Supreme Court No. 320/2530).

The existing provision is meant to protect the women or the wives after the divorce as in the process of getting the divorce; they have suffered a lot especially in managing the house needs and children. By the existence of this provision, when a divorce happens because of the unfaithful act by one of the parties, another party can claim for compensation as it can help to ease his or her problems. In short, the unfaithful party should be responsible of his or her action under the name of lineage and dignity of the victim.

\section{2 c/ddah Maintenance}

clddah maintenance is a claim that makes it compulsory for the husband to pay to the divorced wife throughout the c/ddah period as long as the wife is not nusyuz (disloyal). The obligation of giving the c/ddah maintenance is mentioned in Surah Al-Talaaq, 65:1.

In the Islamic Family Law of the Southern of Thailand, c/ddah maintenance is part of the husband and wife responsibilities. The statement is related to the wife who is divorced by talaaq rajci has the right for a shelter. She is also entitled to get other maintenance such as food, cloth and other things regardless of her pregnancy status. This is in line with the pro vision in the Islamic Family Law of the Southern of Thailand item 307(1);

During the c/ddah period, the wife who is divorced by talaaq rajci and she is not nusyuz (disloyal) is entitled for receiving the clddah maintenance, as she is being a wife.

The clarification of item 307(1) states that the divorced wife in the period of $c / d d a h$ rajci has the right for c/ddah maintenance as long as she is not announced as nusyuz (disloyal). However, the divorced wife in the period of clddah ba'in has different right for the c/ddah maintenance as explained in item 100;

If the wife in the condition of item 92 where she is divorced legally, but she is still in the period of major or minor clddah ba'in by the tacliq or fasakh divorce, and the wife is pregnant, she is entitled to receive the c/ddah maintenance from the husband and his inheritance even though the husband dies during the clddah period. In the context of equipment, it follows item 92 (2) (J), except the wife needs other equipment. Conversely, if the wife is not pregnant, she is not entitled for the $/ d d a h$ maintenance except for the shelter. If the husband gives the $/ d d a h$ maintenance by referring to the first sentence as he misunderstood that the wife is pregnant, she needs to return the right received from her husband.

Based on the above explanation, the law states that if the wife is in the period of c/ddah ba'in (major or minor which is related to the divorce by tacliq or fasakh) and the wife is pregnant, she is entitled for the maintenance until she gives birth. The rate of receiving the c/ddah maintenance is based on the item $92(2)(\mathrm{J})$, except the wife has certain wish, the husband is obligated to fulfil it as long as he is capable of doing that. If the husband dies during the c/ddah period while the wife is pregnant, she is entitled to get the c/ddah maintenance from the husband and the husband's inheritance. However, if the wife is not pregnant, she is not entitled to get the clddah maintenance, except for the shelter as the divorce is by talaaq ba'in. Besides, if the husband gives the c/ddah maintenance to the wife as he believes that she is pregnant, but in reality she is not pregnant, the wife should pay back the amount to the husband.

The same issue is also explained in the provision of Islamic Family Law of the Southern of Thailand in item 101:

The condition of a wife in item 92 who is in the period of clddah because of her husband died, regardless her pregnancy status is not entitled to get the maintenance during clddah except for the shelter.

In the other words, if the divorce happens because of the death of the husband, and the wife is not declared as nusyuz (disloyal), she has no right for the c/ddah maintenance except for the shelter, regardless of her pregnancy 
status. This is because, the wife will get the inheritance of the husband and she is allowed to stay in the shelter during the clddah period ends.

Similarly to the wife who has been divorced by talaaq ba'in, and she is not pregnant, she is only entitled to get the shelter only as the maintenance. That means, it is not compulsory for the husband to prepare the food and cloth for exwife of talaaq ba'in except she is pregnant. The same condition applied to clddah for talaaq rajci, where it is compulsory for the husbands to give maintenance in terms of food, cloth and shelter.

Apart from the matters mentioned earlier, the Islamic Family Law of the Southern of Thailand prohibits the wife from moving out from the husband's house during the period of c/ddah, except for any emergency cases . Likewise, the husband is prohibited from selling the house that is supposed to be the shelter for the wife unless the c/ddah period ends; or he gives other shelter for the wife; or the wife feels uncomfortable or threatened at that place of shelter. This is because, shelter/house is a part of the maintenance given by the husband to his divorced wife, regardless the conditions of divorce whether by talaaq ba'in or talaaq rajci. This is in line with the law provision item 102 in explaining the prohibition for a husband and wife in the period of c/ddah. (The Islamic Family Law of the Southern of Thailand.1946. item 102)

The implementation of the Islamic Family Law of the Southern of Thailand in reality is different from what it is listed in the law provision. Essentially, the divorced wife has the right to claim for the maintenance during the c/ddah period, but the divorced parties do not really concern about this matter, especially the irresponsible husband. That problem leads to the filing of $c / d d a h$ maintenance claim from the wife at the Islamic Council. The situation is really wasting the time of both parties as they have to refer the case back to the Islamic Council until the case is settled. This matter could be settled easier if the husband is responsible and give the c/ddah maintenance. (An Interview: Abdulraman bin Ishak.Committee of the Islamic Council, Pattani. 6/5/2015).

Most of the claims of c/ddah maintenance in the Islamic Council took quite a long time eventhough the cases merely involving little amount of claim. The cases will usually took time such as from 1 to 2 years to be settled. Those cases can actually be solved easier and faster if the husband knows the law and his responsibilities, even though he does not have any intention to reconcile with his ex-wife. (An Interview: Hj.Solahuddin Hj.Abdullatif. 2015. Committee of the Islamic Council, Pattani. 5/5/2015). The implementation of the law of c/ddah maintenance in the four districts of the Southern of Thailand is different from the implementation in the other countries as the rate of the c/ddah maintenance is not clear. The only clear explanation listed is about the law of clddah maintenance which states the obligation of a husband to give c/ddah maintenance and the condition of a wife during the c/ddah period.

In fact, matters related to the claim of c/ddah maintenance, the Islamic Council and Court has power to order the husband to give the c/ddah maintenance to the wife, but it is not clearly stated in that law. As a consequence the implementation of clddah maintenance cannot be enforced upon the husband in cases of his carelessness in giving the c/ddah maintenance (An Interview: Hj Sali Benae. Imam of Yarang Mosque, Pattani. 25/3/2015).

The problem occurs in the four districts of the Southern of Thailand and it has become a common phenomenon where the wives have no channel to appeal and file the case till the women were victimized. In some cases, people try to file petition of claim at the Islamic Council and bring the case to the lower Court. Unfortunately the process usually costs a lot of money and it will prolong till 2-3 years. This has caused part of the local community especially the wives who have been divorced during their c/ddah period just merely refer their cases to the level of district Imam to settle it. . Nevertheless, if the case is not solved, they will not prolong the case to the Islamic Council and Court and end up with keeping quiet till the c/ddah period ends (An Interview: Ahmad Doyi. Imam of Sadawa Mosque, Pattani. 6/5/2015).

In other cases, there are also husbands who divorced their wives by accusing them as committing nusyuz (disloyal) during the marriage in order to prevent the wives's rights in receiving the clddah maintenance by chasing them to leave the house that supposed becaming his shelter during the clddah period. . Similarly to the wives who have been divorced, they will leave the house without the husbands' permission. In addition, the wives' family also supported the action as they believe that once the love relationship ends between the husband and wife, the wife should go back to her parents' house. This is totally wrong as they follow the customs and traditions practised by the society without referring to the Islamic Law as stated in the Quran and Sunnah.

There are different cases of claiming for the $c / d d a h$ maintenance recently, but the obligation of a husband in giving the c/ddah maintenance to the wife needs to be highlighted.

If the husband feels reluctant to pay the c/ddah maintenance, it will be considered as debt which is compulsory to be paid later on. This is because; the obligation is mentioned by Allah (S.W.T) in the Quran that the iddah maintenance is vital to support the divorced wife. The ex-husband needs to consider on the difficulties encountered by the wife after the divorce whereby she needs to manage the house and children on her own. Shortly, it is very crucial for the husband to give the $/ d d a h$ maintenance in order to protect the wife and to comfort them after the divorce.

By referring to the Family Law of Thailand, it is different from the Islamic Family Law of the Southern of 
Thailand as the law basis is different in terms of the law, punishment, creation and belief that are taken from various religions. The Civil Law of Thailand is implemented in all aspects such as law of administration, action and other aspects. It is also implemented in government, politics and majority of the society which come from the Buddhists (Bunchaleam, S. 2011). In protecting the divorced wife, the Civil Law of Thailand does not mention it as Civil c/ddah maintenance, but it functions as the cost of living after the divorce.

According to the provision in the settlement of divorce, there are few items that touch on the cost of living after the divorce. Even though the provision is not parallel to the c/ddah maintenance in the Islamic Family Law of the Southern of Thailand in terms of determining the payment term, condition of divorced wife, reason and need, it still exists in paying for the cost of living after the divorce. The Civil Law of Thailand item 1526 can be understood as follow:

If the divorce is caused by the fault of one of the parties, or the divorce causes one party to become poor, as the party do not get enough income or property during the marriage term, one party can claim the cost of living from another party. The court can determine the cost for that based on the financial and social status of both parties, as guided by the provision of law item 1598/39, item 1598/40 and 1598/4. (Civil and Trade Code Chapter 5 and Chapter 6 item 1526).

A divorce that is caused by one party can be illustrated as the husband does not give the children maintenance, he hurts the wife physically and mentally and the divorce leads to another party to become poor. The problems happen as the wife needs to manage the children, quit the job and the past property is not enough to be used for the current condition. Hence, she can claim for the cost of living from the husband. The rate of cost of living can be decided by the Court by evaluating the financial and social status of both the ex-husband and the ex-wife. The consideration can be guided by the provision of law item 1598/39, item 1598/40 and item 1598/41 for a better decision.

In the court decision mail no. 1106/2550, the defendant claimed that the plaintiff did not give the maintenance for the wife based on the provision item 1461 (Second Paragraph). This situation led the plaintiff to file for a divorce. If the Court decided that they are advised to get divorce, the plaintiff has to pay for the cost of living for the defendant monthly, as the divorce caused the defendant to become poor. This is parallel to the provision of the cost of living written in item 1526 which means; if a divorce is caused by one party leads to the poverty of another party, the claim for cost of living can be asked from the one who causes the divorce. If the court does not advise for the husband and wife to get divorce, the defendant has no right to claim for the cost of living as the marriage is still valid (The judgement of the Supreme Court No. 1106/2550).

In some case, the divorce can cause one party to be crazy or getting dangerous disease, so the other party should pay the cost of living to him or her. The serious impact of divorce pervades the government to protect and take care of them, and not fall under the responsibility of the family and society. This matter is clearly mentioned in the provision item 1527 which means:

If the divorce causes one party to be crazy item 1516(7) or it causes the dangerous disease item 1516(9), one party should pay the cost of living to the victim by considering the cost of living in item 1526.

Meanwhile, the statement in the cost of living also explains the provision item 1528 this means any party which receives the cost of living get into a new marriage, is not entitled to get that anymore. This means, if the husband or the wife gets into a new marriage, the claim for the cost of living should be stopped and the Court order will also be void. In brief, any claim for the cost of living should be filed within one year of the divorce and the case should follow item 1516 (1)(2)(3) or (6) or item 1523. In the Court decision mail no. 6288/2537 and 3190/2549 decides that a claim for cost of living which exceeds one year after the divorce is not valid by referring to item 1528 (The judgement of the Supreme Court No. 6288/2537 and 3190/2549).

The divorced wives should be alert that even though they will face a challenging future after being divorced, they still have the civil and Islamic laws to protect and help them in the issue of Mutcah and c/ddah maintenance by the husband. This is because, the issues are clearly stated in the Quran and Sunnah based on few evidences, as well as in the civil law created by human. The failure to give Mutcah and clddah maintenance to the wife will put the husband in debt that is compulsory to be paid. The wife should know that she has the right to receive a consolation gift and live in the house that used to be her shelter before the divorce. It is a disappointment when the husband easily chases the wife from their house as soon as she is divorced without referring to the law, especially the Islamic law.

\section{Conclusion}

Islam is not only protecting the welfare and rights of women when they are in the marriage term, but it continuously takes place till the marriage is void either the alive divorce or death divorce. It is surely meant to offer of benefit as the Islamic 
law is beyond the human mind. Similarly, the law of Mutcah and c/ddah maintenance is offering benefits to women by Allah (S.W.T). Hence, as the good Muslims, we need to obey and follow the law without much queries or regrets. This is because; obeying the law of Allah (S.W.T) is a sign of worship from the slave towards the ultimate Creator. In the context of working and non-working Thailand women, the roles of the family and society are extremely significant. They should be educated and alarmed on respecting the situation a divorced woman and help them to continue a better life. This is important as the clear understanding regarding this matter can protect the women, especially the widows. The overall study results showed that both the Family Law of Thailand and the Islamic Family Law of the Southern of Thailand recognize the Muctah and c/ddah maintenance right among Muslim women therefore compulsory husband who divorced his wife in order to grant such rights for the during the c/ddah period. Although the Family Law of Thailand is not clearly call Muctah and c/ddah maintenance right, but it turns out in terms of the protection and guarantees given to the Muslim woman who have been divorced by her husband. Thus enough to prove that the rights of women who have been divorced by her husband always exist as long as does not violate the conditions laid down by both the law.

\section{References}

Al-Ansari, A. M, (1949). al-Jami'il al-Quran. No. 18. Egypt: Matbacah Darul Kutub al-Misriyyah.

Al-Dimashqi, T. (1428 H). Kifayatul Akhyar fi Halli Ghoyatil Ikhtishorterbitan. Darul Minhaj.

Al-Khasht, M. U. (1994). Dar al-Kitab al-Arabi. Egypt.

Al-Khatib, S. (1994). Mughniy al-Muhtaj. No. 4 \& 5. Bairut: Darul kutub al-IImiah.

Al-Maumani, I. (2010). al-Ahwal al-Syakhsiyyah fiqah al-Nikah. Oman: Dar al-Maisarah.

Al-Muhammad K. Z. 1996, Bundet. P. (1998) Kham Atibay Pramual Khod Mhay Peng Le' Panith bab 5. Bangkok: Nitibannakran.

Al-Qurtubi, A. A. (1967). al-Jami li Ahkam al-Qur'an. No. 3. Egypt: Dar al-Kitab al-Arabi Li al-Tibaah wan al-Nasr.

Al-Sabuni, M. A.(1977). Rawa'i al-Bayan Tafsir Ayat al-Ahkam Min al-Quran. No. 2. Damshiq: Maktabah al-Ghazali.

Al-Sarkhasiyy, S. D. (n.d.). al-Mabsut. No. 5. Bairut: Dar al-Ma'rifah.

Al-Shairazi, A. I. (1967) al-Muhaddhab fi al- fiqh al-Imam al-Syafi'i. No. 2. Egypt: Matbacah Mustafa al-Babi al-Halabi wa Awladuh.

Al-Shairazi, A. I.(1967). al-Muhaddhab fi al- fiqh al-Imam al-Syafi'i. Ed. 3. No. 2. Egypt: Matbaah Mustafa al-Babi al-Halabi wa Awladuh. Al-Yamani, S. (n.d.). Subul al-Salam. No. 4.

Farj, A. (1990). al-Furqah Bayna al-Zaujayni wa Ahkamuha fi Mazhab ahli al-Sunah. al-Mansurah: Dar al-Wafa.

Ibn Qudamah. (1981). al-Mughni Riyadh. Maktabah al-Riyadh al-Hadithah.Vol. 7.

Louwis, M. (1986). al-Munjid fi al-Lughah. Bairut: Dar al-Masyriq.

Muhammad Kamal K. Zaman. (1996). Fatani 13 Ogos. Kelantan: N.P.

Qalcah, M. R. (2006). Mucjam Lughah al-Fuqaha. Beirut: Dar al-Nafa'is.

Siriporn Lettanongsak, S. (2008). Network for the Advancement of Women and Peace. Bangkok: Chulalongkorn S.W.K.

Zuhayli, W. (1985) al-Fiqh al-Islamiyy wa cAdilatuhu. No. 2. Damshiq: Maktabah al-Ghazali. 